Решетньова Ганна Олексіївна, аспірантка Національної академії образотворчого мистецтва і архітектури

ORCID 0000-0002-5716-3797 rerih686@ukr.net

\title{
МАЙСЕНСЬКА ПОРЦЕЛЯНА У СУМСЬКОМУ ОБЛАСНОМУ ХУДОЖНЬОМУ МУЗЕЇ ІМ. Н. ОНАЦЬКОГО
}

Мета роботи. Проаналізувати ряд порцелянових творів Майсенської фарфорової мануфактури, що надійшли від приватних колекціонерів та нині зберігаються в колекції Сумського обласного художнього музею імені Никанора Онацького. Уточнити атрибуцію творів та ввести український спадок у загальноєвропейський контекст. Методологія дослідження полягала в мистецтвознавчому аналізі наданих для вивчення творів, а також в компаративному аналізі аналогічних предметів. На підставі характеристик предмета-аналога та схожості з предметом дослідження робилися висновки про наявність тих же характеристик у досліджуваного предмета, висувалися припущення про місце та час його походження. Наукова новизна дослідження полягає в новій атрибуції порцелянових предметів з Сумського обласного художнього музею ім. Н. Онацького. Огляд порцелянових творів 3 колекції музею у порівнянні зі світовими аналогами як малої пластики, так $\mathrm{i}$ монументальних об'єктів, вводить предмети української збірки у світовий контекст. Висновки. Українські мистецькі збірки містять значну кількість класичних творів західноєвропейських мануфактур XVIII-XIX ст. Завдяки відкритості фондів, ми ознайомилися лише 3 незначною частиною предметів Майсенської порцелянової мануфактури, що надійшла від приватних колекціонерів та нині зберігається у Сумському обласному художньому музеї ім. Н. Онацького. Внаслідок дослідження було простежено паралелі 3 монументальною скульптурою, здійснено нову атрибуцію трьох предметів та винесено на розгляд датування четвертого. Таким чином, у СХМ зберігаються: алегоричні скульптури «Зима», «Алегорія весни» або «Флора», «Алегорія літа» або «Церес (Церера)» - $з$ колишньої колекції $Є$. Русакової; «Викрадення Прозерпіни» зі збірки Е. Захар'ян. Уточнено роки створення моделі фігури «Жінка, що сидить на пуфику», місце походження предмету потребує подальшого дослідження. Висновки, що були зроблені під час аналізу, дозволяють стверджувати, що окрім клейма та предметів аналогів, виріб можна атрибутувати завдяки стилістичним особливостям, манері розпису та кольоровим нюансам.

Ключові слова: фарфор, порцеляна, атрибуція, Майсенська фарфорова мануфактура, Сумський художній музей, приватна колекція.

Решетнёва Анна Алексеевна, аспирантка Национальной академии изобразительного искусства и архитектуры

Майсенский фарфор в Сумском областном художественном музее им. Н. Онацкого

Цель работы. Проанализировать ряд фарфоровых изделий Майсенской мануфактуры, которые поступили от частных коллекционеров и ныне хранятся в коллекции Сумского областного художественного музея имени Никанора Онацкого. Уточнить атрибуцию предметов и внести украинское наследие в общеевропейский контекст. Методология исследования заключалась в искусствоведческом анализе предметов взятых для изучения, а также в компаративном анализе аналогичных изделий. На основании характеристик предмета-аналога и сходства с предметом исследования делались выводы о наличии тех же характеристик у исследуемого предмета, выдвигались предположения о месте и времени его происхождения. Научная новизна исследования заключается в новой атрибуции фарфоровых предметов из Сумского областного художественного музея им. Н. Онацкого. Обзор фарфоровых произведений из коллекции музея в сравнении с мировыми аналогами, как малой пластики, так и монументальных объектов, введение предметов украинского собрания в мировой контекст. Выводы. Украинские художественные собрания содержат значительное количество классических произведений западноевропейских мануфактур XVIII-XIX вв. Благодаря открытости фондов, мы ознакомились только с незначительной частью предметов Майсенской фарфоровой мануфактуры, которые поступили от частных коллекционеров и ныне хранятся в Сумском областном художественном музее им. Н. Онацкого. В результате исследования были прослежены параллели с монументальной скульптурой, осуществлена новая атрибуция трех предметов и вынесена на рассмотрение датировка четвертого. Таким образом, в СХМ хранятся: аллегорические скульптуры «Зима», «Аллегория весны» или «Флора», «Аллегория лета» или «Церес (Церера)» - из бывшей коллекции Е. Русаковой; «Похищение Прозерпины» из собрания Э. Захарьян. Уточнены годы создания модели фигуры «Женщина, сидящая на пуфике», место происхождения предмета требует дальнейшего исследования. Выводы, сделанные при анализе, позволяют утверждать, что кроме клейма и предметов аналогов, изделие можно атрибутировать благодаря стилистическим особенностям, манере росписи и цветовым нюансам.

(C) Решетньова Г. О., 2019 
Ключевые слова: фарфор, атрибуция, Майсенская фарфоровая мануфактура, Сумской художественный музей, частная коллекция.

Reshetnova Hanna, a post-graduate student of the National Academy of Fine Arts and Architecture

Meissen Porcelains in N. Onatskyi Sumy Region Museum of Art

Purpose of the article: Analysing of a number of Meissen porcelains received from private collectors and currently stored in the collection of Nykonor Onatskyi Sumy Region Museum of Art; The refined attribution of artworks and making the Ukrainian Meissen porcelain heritage known in the general European context. The methodology applied in the study included the art expert analysis of artworks made available for the study and comparative analysis of similar items. Characteristics of similar items and their similarity to studied items underlie the conclusions on availability of the same characteristics in a studied item and the assumptions in respect of the place and time of its origination. The scientific novelty of the study is due to the new attribution of porcelain items kept in $\mathrm{N}$. Onatskyi Sumy Region Museum of Art. The overview of the porcelains in the Museum's collection in comparison with world equivalents (both, figurines and monumental items) makes porcelains of the Ukrainian collection known in the global context. Conclusions. Ukrainian art collections contain a number of classic artworks manufactured in Western Europe in the $18^{\text {th }}-19^{\text {th }}$ centuries. Open collections enabled our studying of only a small part of Meissen porcelains received from private collectors and currently kept in N. Onatskyi Sumy Region Museum of Art. The study resulted in the finding of similarities with monumental sculptures, the new attribution of three items and pending review of the fourth item. Thus, the collection of N. Onatskyi Sumy Region Museum of Art includes Winter, Spring Allegory or Flora, Summer Allegory or Ceres allegoric sculptures from the former collection of Ye. Rusakova; Abduction of Proserpine from the collection of E. Zakharyan. The more accurate origination years of the Woman Sitting on the Pouf figure have been ascertained, while the origination place of this item requires further study. The conclusions made in the course of the study suggest that artwork may be attributed not only on the basis of the marking and similar items, but also based on its stylistic features, painting style, and color peculiarities.

Key words: China, porcelain, attribution, Meissen porcelains, the Sumy Museum of Art, a private collection.

Актуальність теми дослідження. В українських музейних колекціях збережена значна кількість творів західноєвропейської порцеляни. Проте дослідження в галузі декоративно-ужиткового мистецтва, а саме - фарфору, обмежується переважно місцевими виробництвами. Західноєвропейські зразки часто оминаються або згадуються лише під час тематичних виставок. Через обмеження доступу до колекцій та відсутності обговорення - зустрічаємо помилки в атрибуції творів навіть у музеях національного масштабу.

Мета дослідження. Проаналізувати ряд порцелянових виробів Майсенської фарфорової мануфактури, що надійшли від приватних колекціонерів та нині зберігаються в колекції Сумського обласного художнього музею імені Никанора Онацького. Уточнити атрибуцію творів та ввести український спадок у загальноєвропейський контекст.

Аналіз останніх досліджень та публікацій. Вивченням порцеляни Майсенської мануфактури займалося досить багато закордонних дослідників. Вітчизняні публікації містять здебільш переклади, що обумовлено повною довірою іноземним експертам. Задля атрибуції творів у даному дослідженні було залучено загальні праці, що містять історію виробництва та торкаються етапів розвитку $[5 ; 7 ; 10 ; 12 ; 16]$. При пошуку аналогів в роботі використовувалися каталоги великих закордонних збірок $[1 ; 8 ; 11]$ та відомі іноземні аукціони.

Виклад основного матеріалу дослідження. В процесі вивчення стилістичних особливостей порцеляни $з$ українських приватних збірок, що надійшли до музейних фондів, було опрацьовано колекції державних установ Києва, Харкова, Одеси, Сум. В результаті було виявлено похибки або не повні дані стосовно ряду предметів. Певним чином це могло бути пов'язано з відсутністю відповідної літератури та джерел, закритістю кордонів, що заважало попередникам зробити повноцінну характеристику предметів. Враховуючи, що нові відкриття у дослідженні європейської порцеляни постійно здійснюються, відкриваються західні колекції, ми можемо простежити аналоги та по новому поглянути на речі, що зберігаються у фондах нашої країни.

На жаль, частина музейних установ не відкрита до співпраці з незалежними дослідниками. Проте рухи, які споглядаємо в обласних музеях на прикладі Сум та Одеси, дають надію, що й інші музеї вимушені будуть змінювати політику стосовно відкриття фондів.

Після ознайомлення 3 колекцією Сумського художнього музею ім. Никанора Онацького (CXM), за сприянням директора Н. С. Юрченко та завідувача фонду декоративного мистецтва Л. К. Федевич, ми опрацювали інвентарні картки з творами, що надійшли до музею від приватних власників. Увагу привернули предмети, що поступили від харківського колекціонера С. Русакової. В збірці були класичні твори Майсенської порцелянової мануфактури періоду розквіту, на кшталт алегоричної фігури «Зима» (дана та всі наступні назви взято з інвентарних карток музею), яка, немов 
алегорія в барокових спектаклях, була своєрідним прологом діяльності Майсенської мануфактури та епілогом епохи бароко. На білому постаменті прикрашеному рельєфними, злегка позолоченими, завитками, стоїть оголений літній чоловік. Його тіло частково прикриває драперія 3 хутряною підкладкою, яка кріпиться на стегні та огортає чоловіка за спиною та навколо голови. Край тканини чоловік тримає правою рукою, ліва відставлена в бік, немов гріється над вогнищем. 3 лівого боку, трохи позаду розміщено постамент, який за кольоровою гамою перегукується з базою та містить блакитні деталі схожі більш на хмаринки аніж на сніг. На білому постаменті, який нагадує жертовник, лежать світло коричневі дрова 3 помаранчево-червоними відгалуженнями - імітація невеликого вогнища.

Незважаючи на алегоричність, активний рух фігури, звертаємо увагу на кольорову гаму та декоративні елементи, які стають більш округлими, плавними, світлими. Навіть зелений колір драперії та помаранчевий (вогню) - пом'якшені, виконані більш на нюансах, аніж контрастах. Дане припущення підтверджено й історичними фактами: модель «Зима» створено за часів Й. Й. Кендлера у 1750-1760-ті рр., але молодим скульптором Ф. Е. Мейером [1, іл.194]. І якщо Кендлер народився за часів бароко і вимушений був прилаштовуватися до рококо, то Мейер вже «народився» у новому стилі. Мала пластика у його виконанні, як перехідний етап, містить риси манірності: немов натягнута крива, яку порівнюють з «кривою» Ф. Бустеллі $[10,58]$ (роботу якого також можемо бачити в СХМ).

Сюжет же «Зими» абсолютно бароковий. Інколи, при пошуках даної іконографії, відсилають до «Іконології» Ч. Ріпа [9]. Проте, відоме нам зображення з даного джерела 1709 р. зовсім не збігається з порцеляновим твором. У Ч. Ріпа зиму уособлює жінка, що сидить біля голого дерева, поруч з нею кабан. Сдине, що перегукується - слабке полум'я. Біля правої ноги майсенської фігури чаша 3 жевріючим вугіллям. В жертву матінці землі принесено людське життя, яке палало вогнем та згасає з приходом «зими». Зміна пори року, як зміна поколінь. Фігура чоловіка не статична, вона мов полум'я - персоніфікація згасаючого вогню.

Прослідковуємо аналоги майсенської «Зими» й серед творів відомих майстрів. Якщо звернутися до перших років роботи мануфактури, то слід відзначити, що першочергово скульптуру створювали запрошені майстри. Одним 3 таких авторів був Й. Й. Кретчмар (1677-1740), учень відомого представника барокових тенденцій у скульптурі - Бальтазара Пермозера $[8,58]$. Останній у свою чергу був фактично посередником між італійським та німецьким бароко - після навчання та роботи в Італії був запрошений Августом Сильним для виконання скульптурних робіт у Цвінгері, де потоваришував 3 учителем Й. Кендлера - Б. Тома $[16,405]$. В Німецькому національному музеї (Нюрнберг) зберігається фігура «Зима» зі слонової кості, виконана автором 3 кола Пермозера, імовірно - Кретчмаром у 1710-1720-ті рр. Одразу стає зрозумілим поява сюжету на порцеляновій мануфактурі. Проте, якщо згадати більш ранню скульптуру Ф. Жирардона (1675-1679) у Версалі, виникає думка, що можливо саме вона слугувала прототипом для роботи Мейера, адже Кендлер особисто у 1749 р. побував у Франції $[10,157]$ та привіз звідти нові враження та захоплення стилем Людовіка XV. Цілком ймовірно, що «Зима» була створена під впливом саме французького майстра.

Виходячи $з$ цього, підкреслюємо, що зображення сезонів було дуже популярною темою не тільки в Німеччині й не тільки у скульптурі. Музичні твори Вівальді першої чверті XVIII ст. присвячені чотирьом порам року з сонетами, що були написані до них, фактично ілюструються матеріальними культурними творами: живописом, декоративно-ужитковим мистецтвом. Варто згадати абсолютно рокайльний алегоричний автопортрет у вигляді зими 1731 р. італійської художниці Розальби Кар'єри, або сентиментальне зображення старця, що гріє руки у вогнища від нашого земляка В. Боровиковського. Як Монтеверді звертається до внутрішнього світу людини, розкриваючи за допомогою музики їі почуття та емоції, так і художник за допомогою алегорій та персоніфікацій зображає не тільки пори року, а й стан душі, пору життя, яка інколи може й не відповідати віку.

В колекції Русакової зберігався ще один порцеляновий твір - «Жінка $з$ гірляндою квітів». Фігура жінки у повний зріст, виконана на білому постаменті близькому до алегоричної скульптури зими (з пластичними елементами місцями покритими позолотою, проте нижчому). Позаду, немов опора - стовбур дерева зелено-коричневого кольору. Вдягнута жінка в умовний хітон білого кольору прикрашений різнобарвними квітами, що залишає оголеною праву грудь, та плащ світло-бузкового кольору. В iї руках - гірлянда з різних квітів, як за кольором, так і за сортом рослин. По віднайденим нами аналогам, спробуємо уточнити назву та припустити, що це скоріш за все «Алегорія весни» або «Флора». Адже, як влучно відмітили на виставці «Міфи та алегорії в образотворчому мистецтві»: «Зовнішній вигляд богів та властиві їм атрибути зберігалися протягом століть, 3 поширенням християнства набуваючи алегоричне значення. Так, наприклад, Флора, богиня квітів, стала алегорією 
весни, богиня землеробства Церера - літа, бог виноробства Вакх - осені, Борей, який уособлював північний вітер - зими. Згодом і самі пори року стали алегорією основних етапів життя людини - від народження до смерті» [3].

Відповідно до цього розуміємо, що предмет тієї ж колекції, який атрибутується згідно 3 інвентарною карткою СХМ як «“Алегорія осені” (“Жінка зі снопом”)» - дійсно представляє собою жінку, яка уособлює пору року, але трохи іншу. Перед нами фактично гречанка 3 напівприкритим оголеним тілом. Драперія бузково-фіолетового кольору зі світло зеленим підкладом огортає їі тіло, залишаючи відкритим ліве плече та грудь. Босоніж, немов тільки-но скінчивши ритуальний танець, вона у легкому русі предстає перед глядачем. В правій руці жінка тримає коричнево-вохристий сніп, в лівій - не зрозумілий предмет такого ж кольору (ріг - за інвентарною карткою). Волосся жінки, яке за кольоровою гамою перегукується зі снопом увінчує світло-зелений вінок з листя. Справа на невисокому п'єдесталі з рокайлевими елементами стоїть вохристий кошик з плодами. За спиною жінки світло зелене створіння, яке має ознаки втрат та по залишках нагадує дракона.

На основі зібраного матеріалу, дозволяємо собі зробити нову атрибуцію та називати фігуру «Церес (Церера)» або «Алегорія літа». Згадуючи графічні роботи для скульптур Версальського парку відомого художника Ш. Лебрена, ми бачимо алегорії вже відмінні від рекомендацій Ч. Ріпа: того ж старця, як алегорію зими, та жінку з серпом та снопами, як персоніфікацію літа. Вже згадуваний Пермозер також періодично зображав «Літо» та «Цереру» зі снопами поруч із «Бахусом» (майже за сонетами Вівальді). Навіть Пітер Брейгель Старший використовує зображення пшеничного поля, снопів, жнива - при демонстрації останнього літнього місяця. Що ж стосується аналогів 3 Майсенської мануфактури, то в каталозі К. Бутлер одна 3 моделей Ф. Е. Мейера, що уособлює літо також тримає снопи та колосся [1, іл.82]. На аукціоні «Christie's» було представлено алегоричні порцелянові групи, де помічаємо дуже схожу фігуру атрибутовану як «Богиня Церера» 3 наявним драконом біля ніг та пшеницею у руках [15]. Тому можемо остаточно підтвердити нашу гіпотезу та запропонувати нову назву для музейного експоната.

Таке підкреслене розуміння значущості природних явищ та сезонів перегукується 3 геліоцентризмом Галілея, Декартівським раціоналізмом. Філософські роздуми популярного на той час Лейбніца про символи та символічність, його ідея про перетворення одних видів енергії в інші співпадають 3 фарфоровими перетвореннями: зі звичайних природних копалин створюються твори естетичного споглядання, що фіксують часові тенденції. Більш того, за допомогою алегорій відбувається перетворення енергії звичайного любування на енергію роздумів та розшифровки.

Часи розквіту майсенської пластики прийшлися на період відкриття європейських академій мистецтв. Академія ж, як відомо, завжди надавала перевагу високим жанрам, що було одним 3 факторів чому у бароковий період історичний, міфологічний та батальний жанри виходили на перший план як в образотворчому, так і у декоративно-прикладному мистецтві. Вони яскраво вписувалися своєю експресією, рухом, боротьбою протилежностей у загальну стилістичну концепцію епохи. Порцелянові твори також потрапили під вплив цієї стихії, зображення міфологічних сюжетів апелювало до обізнаності глядача, до його ерудованості. У XXI столітті виникають питання, хто зображений у тій чи іншій сцені. У XVIII ж сторіччі таких питань не виникало.

Одним 3 прикладів характерного барокового сюжету, що знайшов вираження у порцеляні $\epsilon$ твір 3 колекції Е. Захар'ян, який в інвентарних картках СХМ атрибутовано як «Викрадення сабінянки». Напівоголений дорослий чоловік (з бородою та вусами), прикритий брунатною драперією, на своєму плечі обома руками тримає молоду напівоголену дівчину в якої, білою з квітами тканиною, обгорнуто лише тазову частину тулова. Не зважаючи на бароковий порив, емоційність скульптурної передачі, фігура чоловіка стоїть на постаменті з рокайлевими завитками, опорою слугує невелике дерево 3 гілками. Зображення й справді перегукується з відомою римською оповіддю та цілком може вважатися історичним, проте потрібно не забувати, що майже всі вироби малої пластики XVIII ст. наслідують видатні твори монументальної скульптури. Тому, у пошуках аналогів, ми звернулися до відомої роботи XVI ст. Джованні да Болоньї «Викрадення сабінянки» [6, 676-677]. Як влучно зазначила Женевьєва Бреск-Боуті: «Це ані боротьба, ані драма; вона не сперечається: це балет, який зіштовхує два контрастні рухи» $[6,675]$. Викрадач - зовсім молодий чоловік атлетичної статури у якого, на відміну від порцелянової фігури, відсутня корона. Останній атрибут свідчить про коронованість особи. Цей факт, дав нам можливість припустити, що означений сюжет більш схожий на викрадення Персефони (Прозерпіни) Аїдом (правителем підземного царства). Тим паче, що фактично енциклопедична робота Берніні виконана у 1621-1622 рр. для вілли Боргезе перегукується 3 порцеляновим твором. Саме в скульптурі майстра, який змусив мармур бути слухняним як тісто [2, 41-42], у мужнього Плутона (Аїда) присутня борода, вуса та корона. Аналогічний вигляд має 
даний герой і у французького скульптора Жирардона. Отже, проаналізувавши твори Майсенської мануфактури саме по міфологічній тематиці, було знайдено аналогічні вироби до представленого в музеї - виконані за моделлю Кендлера середини XVIII ст. [1, іл. 135-136; 4; 14]. Відтак, можна впевнено стверджувати, що робота, яка надійшла від Е. Захар'ян атрибутується як «Викрадення Прозерпіни».

Окремим пунктом слід зазначити датування виробів, адже, незважаючи на подібність творів, час виготовлення деяких предметів відрізняється на ціле століття (експонат СXM, за інвентарною карткою, датовано XVIII ст., подібні західні експонати - як серединою XVIII, так і другою половиною XIX ст.). Цей факт свідчить про те, що аналізуючи лише формалістичні особливості порцеляни, ми не можемо стовідсотково датувати виріб, робити остаточні висновки та експертну атрибуцію. Пояснюється це тиражуванням моделей, яке виконується на заводі й досі. Наразі, роблячи формальний опис ми можемо лише припустити час створення першої моделі, або, що значно гірше стиль епохи, якою надихався майстер.

Як приклад - виріб з СХМ «Жінка, що сидить на пуфику» (з колекції Русакової) виконано у стилістиці пізнього рококо з класицистичними елементами. Твір створено за зразком французького майстра М. В. Ас' $€$, який переїхав до Майсену з Парижа $[5,148]$ та привіз із собою аромат красунь Жана Батіста Грьоза та сентиментальні настрої раннього класицизму. Ми бачимо у руках жінки невелику книжечку, що, як атрибут, було характерним для епохи просвітництва, особливо у французьких колах зманіжених панянок. У формі, незважаючи на пишність плаття, рум'яність щічок та припудреність волосся, помічаємо зміну бази на якій розміщено фігуру: зовсім відсутні рельєфні рокайлеві елементи, що були характерні для попередніх виробів. Абсолютно рівна білосніжна поверхня, лише по периметру ритмічно повторюваний профільований декор, який хоч і має хвилеподібні вигини, проте повністю вказує на нові смаки та епоху, що диктує свої правила та вподобання.

Твір в музеї зазначено як роботу Майсенської мануфактури (хоча, судячи 3 інвентарної картки, клеймо викликає ряд питань) та датовано 60-70-ми рр. XVIII ст. - часи роботи Ас'є. Відомі аналоги на аукціонах атрибутовано 60-80-ми pp. XIX ст.. Аналізуючи кольорову гамму твору, схиляємося до думки, що (при підтвердженні майсенського виробництва) виріб з СХМ створено наприкінці XVIII - на початку XIX ст. (не 60-ті pp., адже сама модель була розроблена у 17761777 pp. [13]). Пояснюємо тим, що вироби другої половини XIX ст., у зв'язку із поверненням моди на рококо, оформлені у більш світлих, ніжних тонах. Виходячи з цього, формулюємо ще один висновок: під час аналізу порцелянового твору необхідно враховувати не тільки форму, сюжет, а й кольорове рішення, порівнюючи предмет дослідження з предметами аналогами.

Висновки. Українські мистецькі збірки містять значну кількість класичних творів західноєвропейських мануфактур XVIII - XIX ст. Завдяки відкритості фондів, ми ознайомилися лише 3 незначною частиною Майсенської порцелянової мануфактури, що надійшла від приватних колекціонерів та нині зберігається у Сумському обласному художньому музеї ім. Н. Онацького. Внаслідок дослідження було простежено паралелі з монументальною скульптурою, здійснено нову атрибуцію трьох предметів та винесено на розгляд датування четвертого. Висновки, що були зроблені під час аналізу дозволяють стверджувати, що окрім клейма та предметів аналогів, виріб можна атрибутувати завдяки стилістичним особливостям, манері розпису та навіть кольоровим нюансам.

Перспективи подальших розвідок полягають в остаточному встановленні виробництва фігури «Жінка, що сидить на пуфику» та подальшому перегляді картотеки західноєвропейської порцеляни 3 колекції СХМ задля внесення нових даних та уточнення відомої інформації.

\section{Jimepamypa}

1 Бутлер К. Мейсенская фарфоровая пластика XVIII века в собрании Эрмитажа : каталог. Ленинград : Аврора, 1977. 33 [158] с.

2 Мастера искусства об искусстве : в 7 т. / ред. И. Я. Цагарелли. Москва : Искусство, 1967. Т. 3. 632 с.

3 Мифы и аллегории в изобразительном искусстве. Всероссийский музей декоративно-прикладного и народного искусства : веб-сайт. URL: http://www.vmdpni.ru/data/events/2016/03/mifi_i_allegoriya/index.php (дата звернення: 12.04.2019).

4 A Meissen Group «The Rape of Proserpine». Christie's Auction House. URL: https://www.christies.com/lotfinder/Lot/a-meissen-group-the-rape-of-proserpine-5067125-details.aspx _ (дата звернення: 23.04.2019).

5 Burton W. A General History of Porcelain : in 2 volumes. London, New York, Toronto, Melbourne : Cassel and Company, 1921. V. 2. 228 p. (Copyright BiblioLife, LLC). 
6 La sculpture : De la Renaissance au XXe siècle, du XVe au XXe siècle : in 2 volumes / ouvrage dirigé par G. Duby, J.-L. Daval. Köln : Taschen, 2010. V. 2. 1149 p.

7 Meier G. Porzellan aus der Meißner Manufaktur. Berlin : Henschelverlag Kunst und Gesellschaft, 1981. $206 \mathrm{p}$.

8 Meißener Porzellan des 18.Jahrhunderts. Die Stiftung Ernst Schneider in Schloß Lustheim / herausgegeben von R. Eikelmann. München : C. H. Beck, 2004. 448 p.

9 Ripa C. Iconologia: or, Moral Emblems. London : Printed by Benj. Motte, 1709. 190 p. URL: https://archive.org/details/iconologiaormora00ripa (дата звернення: 22.04.2019) [in English].

10 Rollo C. Continental Porcelain of the Eighteenth Century. London : Ernest Benn Limited University of Toronto Press, 1964. 198 p.

11 Sammelfiguren. Figure Collectibles : katalog / autor des einleitenden artikels L. Werner. Meissen, 2016. $181 \mathrm{p}$.

12 Schuster B. The Porcelain Museum of Porzellan-Manufaktur Meissen. Leipzig : Edition Leipzig in der Seemann Henschel GmbH \& Co. KG, 2008. 128 p.

13 Sotheby's : Details \& Cataloguing. URL: http://www.sothebys.com/en/auctions/ecatalogue/2005/europeanceramics-silver-and-vertu-w05731/lot.74.html?locale=en (дата звернення: 12.04.2019).

14 The Rape of Proserpine. Victoria and Albert Museum : website. URL : https://collections.vam.ac.uk/item/O306838/the-rape-of-proserpine-figure-group-kandler-johann-joachim/ (дата звернення: 23.04.2019).

15 Two Small Meissen Mythological Figure Groups. Christie's Auction House. URL: https://www.christies.com/lotfinder/lot/two-small-meissen-mythological-figure-groups-early-4978739-details.aspx (дата звернення: 22.04.2019).

16 Walcha O. Meissner Porzellan. Dresden : VEB Verlag der Kunst, 1973. 444 p.

\section{References}

1. Butler, K. (1977). $18^{\text {th }}$ Century Meissen China Plastics in the Hermitage Collection : Catalogue. Leningrad : Avrora [in Russian].

2. Cagarelli, I. (Ed.). (1967). Arts Explained by Masters of Arts (Vol. 3). Moscow : Iskusstvo [in Russian].

3. Myths and Allegories in Fine Arts. All-Russian Decorative Art Museum. URL: http://www.vmdpni.ru/data/events/2016/03/mifi_i_allegoriya/index.php [in Russian].

4. A Meissen Group «The Rape of Proserpine». Christie's Auction House. URL: https://www.christies.com/lotfinder/Lot/a-meissen-group-the-rape-of-proserpine-5067125-details.aspx.

5. Burton, W. (Ed.). (1921). A General History of Porcelain (V. 2). London, New York, Toronto, Melbourne : Cassel and Company [in English].

6. Duby, G., Daval, J.-L. (Eds.). (2010). La sculpture : De la Renaissance au XXe siècle, du XVe au XXe siècle (V. 2). Köln : Taschen [in French]. [in German].

7. Meier, G. (1981). Porzellan aus der Meißner Manufaktur. Berlin : Henschelverlag Kunst und Gesellschaft

8. Eikelmann, R. (Ed.). (2004). Meißener Porzellan des 18.Jahrhunderts. Die Stiftung Ernst Schneider in Schloß Lustheim. München : C. H. Beck [in German].

9. Ripa, C. (1709). Iconologia: or, Moral Emblems. London : Printed by Benj. Motte. URL: https://archive.org/details/iconologiaormora00ripa [in English].

10. Rollo, C. (1964). Continental Porcelain of the Eighteenth Century. London : Ernest Benn Limited University of Toronto Press [in English].

11. Werner, L. (Ed.). (2016). Sammelfiguren. Figure Collectibles : katalog. Meissen [in German].

12. Schuster, B. (2008). The Porcelain Museum of Porzellan-Manufaktur Meissen. Leipzig : Edition Leipzig in der Seemann Henschel GmbH \& Co. KG [in English].

13. Sotheby's : Details \& Cataloguing. URL: http://www.sothebys.com/en/auctions/ecatalogue/2005/europeanceramics-silver-and-vertu-w05731/lot.74.html?locale=en [in English].

14. The Rape of Proserpine. Victoria and Albert Museum. URL : https://collections.vam.ac.uk/item/O306838/the-rape-of-proserpine-figure-group-kandler-johann-joachim/ [in English].

15. Two Small Meissen Mythological Figure Groups. Christie's Auction House. URL: https://www.christies.com/lotfinder/lot/two-small-meissen-mythological-figure-groups-early-4978739-details.aspx [in English].

16. Walcha, O. (1973). Meissner Porzellan. Dresden : VEB Verlag der Kunst [in German].

Стаття надійшла до редакиії 14.01.2019 p. 